\title{
QUILOMBOS DO VALE DO RIBEIRA, SÃO PAULO: MOVIMENTOS DE DEFESA DE TERRITÓRIOS COLETIVOS FRENTE AO RACISMO AMBIENTAL
}

Luiz Marcos de França Dias (I) $ه$ 
Historicamente, as comunidades quilombolas têm ocupado lugar de subalternização na história oficial, motivado pelo processo de escravização de povos trazidos da África. Elas criaram e recriaram seus espaços e movimentos de resistência às diversas opressões vivenciadas. A organização pela garantia de direitos tem sido necessária desde os primeiros passos em solo brasileiro, perpassando os dias atuais. Antes, eram fugas e rebeliões; hoje, o embate é contra os entraves na demarcação territorial, a ausência de políticas públicas e o racismo ambiental praticado pelo Estado ou por agentes privados. Assim, o movimento quilombola continua fundamental para a defesa da vida e do território coletivo.

Palavras-chave: comunidades quilombolas; Vale do Ribeira; racismo ambiental.

\section{QUILOMBOS OF VALE DO RIBEIRA (SP): MOVEMENTS TO DEFEND COLLECTIVE TERRITORIES AGAINST ENVIRONMENTAL RACISM}

\section{ABSTRACT}

Historically, quilombola communities have occupied a place of subordination in the official history, motivated by the enslavement process of African people. These communities have created and continually recreate their spaces and movements of resistance to the various forms of oppression experienced. The organization for the assurance of rights has been necessary since the first steps into Brazil, extending to the current days. In the past there were escapes and rebellions, today the fight is against the obstacles of territorial demarcation, absence of public policies and environmental racism practiced by the State or private agents. Thus, the quilombola movement remains fundamental for the defense of life and the collective territory.

Keywords: quilombola communities
QUILOMBOS DEL VALE DO RIBEIRA (SP): MOVIMIENTOS DE DEFENSA DE TERRITORIOS COLECTIVOS FRENTE AL RACISMO AMBIENTAL.

\section{RESUMEN}

Históricamente las comunidades quilombolas han ocupado un lugar de subordinación en la historia oficial, motivado por el proceso de esclavitud de los pueblos traídos de África. Estas comunidades crearon y recrearon sus espacios y movimientos de resistencia frente a las diversas opresiones experimentadas. La organización para la garantía de derechos ha sido necesaria desde sus primeros pasos en suelo brasileño, y hasta el día de hoy. En el pasado eran escapes y rebeliones, hoy la lucha es contra los obstáculos en la demarcación territorial, contra la ausencia de políticas públicas y el racismo ambiental practicado por el estado o por agentes privados. Así, el movimiento quilombola continúa siendo fundamental para la defensa de la vida y el territorio colectivo.

Palabras clave: comunidad quilombola; 


\section{INTRODUÇÃO}

Este artigo é parte da pesquisa de mestrado intitulada "Comunidades quilombolas em territórios coletivos do Vale do Ribeira (SP): saberes da roça em construção de um projeto político epistêmico". Portanto, constitui-se num recorte cujo objetivo é o de discorrer sobre os movimentos quilombolas de defesa às comunidades e a atuação deles frente às ameaças históricas, principalmente territoriais, vivenciadas pelos povos quilombolas. A abordagem é realizada a partir das comunidades quilombolas do Vale do Ribeira, em São Paulo, que solicitaram junto ao Instituto do Patrimônio Histórico e Artístico Natural (IPHAN) o registro do Sistema Agrícola Tradicional Quilombola, reconhecido como patrimônio cultural imaterial brasileiro no ano de 2018. No contexto dessa região, o território não diz respeito somente ao pedaço de chão onde a moradia se encontra instalada ou à cerca que faz divisa com as terras do vizinho, mas remete à ancestralidade; à memória ancestral; aos modos de se relacionar com o próximo, com a terra e tudo presente nela - a mata, o rio, as águas, os peixes -; ao conhecimento acumulado por séculos e partilhado pelas gerações através da oralidade, presente em diferentes momentos do cotidiano que permeiam o ato de educar, coletivamente, as crianças; às formas de organização e gestão do território; e aos modos de fazer inscritos na roça de coivara. Desta forma, o território não pertence só a mim ou uma única outra pessoa ou família, mas a todos os seres.

Ao usar neste texto a primeira pessoa, marco meu lugar de fala enquanto pesquisador, docente e, sobretudo, quilombola, residente em um território ancestral. Há, aqui, a propositura de uma epistemologia que considere o pessoal e o subjetivo como integrantes do discurso acadêmico, entendendo que todos nós falamos a partir de tempo, realidade e lugar específicos, de "uma história e uma realidade específicas" (Kilomba 2019:58). Ocupo, assim, o lugar de ator, ao presenciar muitas das experiências aqui apresentadas, e autor, cuja função está ligada ao processo de interlocução entre os saberes ancestrais quilombolas e a academia.

Considerando os objetivos propostos, a metodologia adotada para este escrito consiste em um estudo teórico-conceitual, fundamentado em análises bibliográficas e documentais sobre as comunidades quilombolas do Vale do Ribeira, tendo como base autores e autoras da perspectiva descolonial. É a partir desse contexto que será abordada não somente a concepção de território para tais povos, mas como esses locais são ameaçados historicamente por diferentes agentes externos às comunidades. E incluem-se num rol de entraves a ausência e a morosidade de regularização das 
terras ancestrais, que, aliadas a práticas de racismo ambiental, ocasionam a ausência de políticas públicas e ameaçam a vida e a cultura de tais povos em seus territórios coletivos de direito.

\section{TERRITÓRIOS COLETIVOS: RESISTÊNCIA EM DEFESA DA VIDA}

No contexto das comunidades quilombolas do Vale do Ribeira, São Paulo, foco deste artigo, há uma relação de respeito e de igualdade entre todos os viventes que habitam o espaço que é determinado de território. Ninguém entra na mata sem pedir permissão, ninguém retira dela o que não é realmente necessário (Luiz et al. 2020), nenhuma árvore é derrubada simplesmente porque as folhas dela incomodam ao caírem no meio de uma via, quando secas. O território não se resume somente a uma base material, fundamental à comunidade e às práticas das pessoas que nele habitam, mas está ligado a todas as formas de vida presentes no espaço. Tal modo de vida difere dos moldes e padrões impostos pelo capitalismo na modernidade/ colonialidade, pautados na exploração de pessoas e na transformação de matas, rios, rochas, entre outros, em recursos financeiros.

Conforme aponta Beatriz Nascimento (1985:59), o conceito de território trazido pelas comunidades quilombolas ao longo do tempo não se resume apenas ao campo geográfico, mas se estende ao nível de uma simbologia que inclui homens e mulheres com direito à terra e ao espaço ocupado dentro de um sistema maior. Já na visão de Milton Santos (2000), é no território que se baseiam o trabalho, a residência, as trocas de âmbito material e espiritual e a vida, aspectos que são influenciados por ele. Assim, não diz respeito somente à criação do homem, mas consiste em uma identidade composta pelo chão e pela população que nele habita, compondo uma identidade que reflete o sentimento de pertença (M. Santos 2000:96) a seu próprio lugar de direito.

As formas de gestão política do território quilombola e das relações interétnicas podem variar conforme cada comunidade, levando em consideração o contexto regional, social e político; porém, a mesma concepção do território como fonte de produção da vida - e não só humana - é evidenciada nas comunidades quilombolas do Vale do Ribeira, em diferentes contextos e momentos históricos, explícita nas reivindicações, lutas e processo de resistência às opressões, que estão ligados à defesa da natureza e também à memória coletiva, que remete à ancestralidade negra.

No final do ano de 2018, algumas comunidades do Vale do Ribeira receberam inesperada e indesejável visita de dois representantes de uma 
mineradora multinacional, demonstrando grande interesse na exploração de minérios nos territórios ${ }^{1}$, propondo conversa sobre projetos que, segundo eles, desenvolveriam a região, trariam mais pessoas, escolas, postos de saúde e melhorariam a vida dos ali já residentes. No Quilombo São Pedro, após um tempo de conversa, uma liderança comunitária levantou um dos braços e, apontando para um grupo de crianças que brincava sob a sombra de uma árvore, disse que o território não estava em negociação e nem à venda, pois, da mesma maneira que fora herdado dos ancestrais, seria repassado àqueles que ali brincavam. E no mesmo tom, outra liderança comunitária pontuou ser fundamental a manutenção da floresta em pé e dos rios correndo livres, proporcionando, assim, vida a todas as espécies que neles habitam, para além dos seres humanos, finalizando com o discurso de que aquela comunidade não compactuava com o tipo de desenvolvimento ali proposto pelos representantes da mineradora, que, por sua vez, agradeceram a atenção a eles dispensada e não mais retornaram.

O exemplo ilustrado mostra o assédio por parte de empresas a territórios quilombolas, que facilmente se confundem com relatos de muitas outras comunidades do país. As propostas de mineradoras, madeireiras e outros propositores de megaempreendimentos são embasadas numa visão de desenvolvimento pautada no capitalismo. Por outro lado, porém, na compreensão das comunidades quilombolas, a natureza e a cultura são indissociáveis e, por isso, a "re-existência" desses povos e demais comunidades tradicionais reflete "os gritos de socorro dos rios mortos, da fauna, da flora e da totalidade da vida usurpada" (Silva \& Moraes 2019:42). Nesse sentido, evidenciam-se diferentes concepções de território, sendo uma pautada no sistema capital/moderno, defendida pelos representantes da empresa, e outra numa concepção ancestral quilombola.

Essa relação entre humano e não humano/ natureza é concebida de formas diferentes por diversas sociedades. Segundo Walter Mignolo (2017), a colonialidade propiciou o envolvimento da natureza e dos 'recursos naturais' em uma complexidade pautada na cosmologia ocidental. Estruturado ao longo de séculos na teologia, fabricando também um sistema epistemológico legitimador dos usos da natureza, com finalidade de geração de “quantidades maciças de 'produtos'

1 Criada pelo Decreto-Lei $n^{\circ} 764 / 2015$, a Companhia de Pesquisa de Recursos Minerais (CPRM) é uma empresa governamental brasileira vinculada ao Ministério de Minas e Energia, responsável pelo Serviço Geológico do Brasil. Embora a sua missão seja "gerar e disseminar conhecimento geocientífico com excelência, contribuindo para melhoria da qualidade de vida e desenvolvimento sustentável do Brasil" (CPRM s/d), entre a década de 1980 e o início dos anos 1990, a estatal realizou várias pesquisas e levantamentos em diversos territórios quilombolas do Vale do Ribeira, sendo os moradores desconhecedores dos trabalhos realizados, bem como dos materiais encontrados. 
agrícolas, primeiro, e quantidades maciças de 'recursos naturais' após a Revolução industrial” (Mignolo 2017:8), quando o conceito foi transformado a natureza "se tornou repositório para a materialidade objetivada, neutralizada e basicamente inerte que existia para a realização das metas econômicas dos 'mestres' dos materiais” (Mignolo 2017:8). Dessa maneira, os reflexos e impactos dessa transformação persistem na atualidade, "em nossa presunção de que a 'natureza' é o fornecedor de 'recursos naturais' para a sobrevivência diária: a água como mercadoria engarrafada" (Mignolo 2017:7). A forma de concepção da vida das comunidades quilombolas emerge na modernidade como uma afronta ao sistema capitalista/colonial (Silva \& Moraes 2019:37). Este tornou os meios de produção mais modernos, mas continua definindo as regras, determinando aqueles que têm o direito de viver e os outros que merecem morrer, de vidas que poderiam ser descartadas e aquelas que devem ser mantidas (Silva \& Moraes 2019:37), diferindo da visão de mundo pautada na ancestralidade negra, presente nas comunidades quilombolas.

Nas comunidades do Vale do Ribeira, em São Paulo, há uma relação indissociável entre quilombolas/natureza/território/conhecimento ancestral, em que o humano não é um ser à parte, afastado, e sim, um dos elementos, dotado de saberes e experiências, que compõe esse território, da mesma forma que se fazem presentes as árvores, as águas, os animais e todas as demais espécies, numa relação de harmonia. Para Milton Santos (2012:138), “o território são formas, mas o território usado são objetos e ações, sinônimos de espaço humano e espaço habitado”. Portanto, cada sociedade tem uma concepção de uso dele, de acordo com seus preceitos. Enquanto para aquelas sociedades pautadas no capital ele é fonte de riqueza, isto é, de exploração, para os povos e as comunidades tradicionais, o território é a base da vida, onde se produzem e guardam conhecimentos ancestralmente, sendo, no entanto, também um campo de luta, onde diferentes interesses são sobrepostos cotidianamente aos seus direitos. Segundo Milton Santos (2000), no momento em que passam a crescer os comércios internacional e interno, as coisas tendem a se tornar objeto de troca, tendo valores atribuídos pela troca e não pelo uso, e, dessa maneira, o território também passa a ser categorizado, atendendo as leis do valor (M. Santos 2000:48). Em outras palavras, o território passa a ser também mercadoria, na concepção de parte da sociedade.

Essas implicações estão ligadas à modernidade/ colonialidade, determinadas pelas relações sociais, baseadas no racismo, machismo, exclusão social, racismo ambiental, entre outros. É nesse 
contexto que as comunidades quilombolas do Vale do Ribeira estão inseridas, conservando seu projeto político epistêmico, visando uma diferente concepção de desenvolvimento, pautada na sua organização dentro dos movimentos sociais, na criação de estratégias para resistir às opressões, visando assegurar os direitos sociais nas ações políticas de enfrentamento às diferentes exclusões e preconceitos; vislumbrado defender e manter-se em seus territórios coletivos.

No histórico de tais comunidades, podemos citar diversos exemplos de proposituras que direcionam a uma diferente concepção de sociedade, pautada no respeito à vida em territórios coletivos. Um deles é a luta contra a construção de usinas hidrelétricas no rio Ribeira de Iguape 2 , que durou quase 30 anos. A conquista momentânea ${ }^{3}$ não se deu de forma amena e pacífica, e o movimento quilombola foi criando e incorporando táticas de defesa do território. Outra estratégia de ação demandada da organização quilombola em defesa do território foi a solicitação de reconhecimento da roça de coivara quilombola como patrimônio brasileiro junto ao IPHAN, resultado da "articulação das comunidades quilombolas com organizações não governamentais, instituições de pesquisa e órgãos públicos” (A. Andrade et al. 2019). A ação que será detalhada mais adiante teve desdobramento positivo no ano de 2018, com o reconhecimento do bem como patrimônio cultural e imaterial brasileiro.

A partir do fortalecimento da organização focada no direito ao território, leis passaram a ser acessadas, conhecidas e apropriadas, concomitantemente à proposição de reflexão, através da prática, sobre a relação que permeia tais povos, meio ambiente, território e conhecimentos, ensinando (e se relacionando com) a sociedade em geral sobre valores fundamentais que regem a vida, intrínsecos a essas comunidades. A relação com esse território não é de exploração, pois faz-se necessário manter a vida das próximas gerações, numa relação ancorada nos conhecimentos ancestrais, que tangem as formas de vida em sociedade com ideais e práticas coletivas. Desta maneira, "garantir o território às comunidades quilombolas é preservar a memória, as danças, a oralidade, os conhecimentos partilhados de geração em geração, os modos de fazer, os laços

2 No ano de 1988, a Companhia Brasileira de Alumínio (CBA) iniciou um projeto de construção de quatro usinas hidrelétricas (UHE) no Vale do Ribeira. Tais empreendimentos afetariam diretamente tanto a maior reserva de Mata Atlântica do Brasil quanto as comunidades quilombolas, indígenas e pequenos agricultores daquela região. Em 2016, o Instituto Brasileiro do Meio Ambiente e dos Recursos Naturais Renováveis (IBAMA) indeferiu o licenciamento do empreendimento (ISA 2016).

3 Utilizo vitória momentânea porque o sistema capitalista se transforma, se regenera e dificilmente se dá como vencido. Há, neste momento, projetos de construção de 13 pequenas centrais hidrelétricas $(\mathrm{PCH})$ na bacia do rio Ribeira de Iguape (ISA 2018). 
de pertencimento e a ancestralidade negra" (A. Andrade et al. 2019); é garantir a diversidade cultural, que constitui o povo brasileiro e a preservação da natureza, mas não como um conceito abstrato, que envolve somente a mata, e sim com a natureza de cada um que compõe a sociedade.

\section{RESISTÊNCIA PELO TERRITÓRIO: CRIAÇÃO DOS MOVIMENTOS DE DEFESA}

Os processos de subalternização herdados do colonialismo evidenciam que a expropriação de territórios tradicionais está pautada na dominação capitalista global, que enxerga esses locais simplesmente como fonte de geração de recurso financeiro, e não como espaços onde a vida é produzida coletivamente, com valorização e respeito à ancestralidade, vislumbrando a partilha do local com as futuras gerações, para que possam desfrutar dele, garantindo, assim, a continuidade da cultura quilombola. Nesse jogo antagônico de compreensão do território, a história nos apresenta diversas ofensivas às comunidades e a necessidade de reorganização e rearticulação perante novos desafios e demandas que surgem a cada momento. $\mathrm{Na}$ tentativa de exterminar a cessão de direitos e soterrar os já adquiridos está a necessidade da criação do que chamo de movimentos de defesa, conforme exposto adiante.

A resistência no território é pautada no processo de resistência dos nossos ancestrais, que permanecem vivos em todos aqueles que buscam pela liberdade dos povos. Eles se fazem presentes no espírito de luta e resistência de milhares de comunidades quilombolas existentes hoje no Brasil, que demonstram uma proposta de sociedade antirracista e desafiadora na modernidade, frente ao capitalismo. Se hoje a roça de coivara das comunidades do Vale do Ribeira é reconhecida como patrimônio brasileiro pelo IPHAN, por abarcar um grande conjunto de conhecimentos inscritos nas comunidades que permitiu a permanência delas em meio a Mata Atlântica; ontem, o Quilombo dos Palmares também desafiava a política excludente e opressora do Brasil colonial, mostrando-se proponente de uma nova sociedade, evidenciada pela resistência a um total de 27 ataques, estrategicamente assegurados por mais de cem anos (A. Nascimento 1980:47), o que pressupõe a exigência de uma série de conhecimentos. Desde as táticas de guerra, variedade de animais silvestres, tipo de vegetação, estações do ano até a produção de alimentos para a população, bem como fabricação de artefatos para uso cotidiano, ervas medicinais, mas principalmente a organização coletiva. Sem esses saberes acumulados, jamais Palmares resistiria tanto tempo ao poder do Estado organizado, apoiado por outros países. No Vale do Ribeira, as comunidades resistem também através da roça de coivara 
quilombola e de outros elementos ligados a ela. Devido à sua complexidade, exige-se uma gama de conhecimentos necessários ao manejo e também o estabelecimento de uma rede de convivência social (Pedroso Júnior 2008). Estes são fatores primordiais para a sobrevivência dentro da Mata Atlântica e permanência nos territórios por séculos.

Na década de 1970, com o avanço da monocultura na região do Vale do Ribeira e a consequente devastação de imensas áreas, desenvolveu-se em vários segmentos ambientalistas e setores do governo a ideia de que áreas preservadas eram aquelas sem a presença de humanos. Além da criação de Unidades de Conservação (UC) pelo estado de São Paulo, que se sobrepunham aos territórios, as comunidades passaram a enfrentar outras crescentes ameaças que perduram por décadas, como os projetos de construção de usinas hidrelétricas (UHE) no rio Ribeira de Iguape ${ }^{4}$, que afetariam diretamente o modo de vida dos quilombolas, além de projetos de mineração, expansão da monocultura e madeira (A. Andrade et al. 2019), de cunho desenvolvimentista, que desconsideram os povos tradicionais. Tal movimento impulsionou as comunidades a desenvolverem e aprimorarem táticas para a resistência nos seus territórios. Com tais ameaças, são criadas em âmbito regional/ local, a partir do final da década de 1970, as associações comunitárias em cada território. Em 1989, o Movimento dos Ameaçados por Barragem (MOAB) se organizou e, em 1995, as comunidades se uniram, juntamente com organizações ligadas à Igreja Católica, e fundaram a Equipe de Articulação e Assessoria às Comunidades Negras do Vale do Ribeira (EAACONE), com objetivo de assessorar juridicamente tais povos quanto à regularização de seus territórios. Tal entidade existe e tem atuação em nível regional. Ainda no ano de 1995, integrantes de comunidades do Vale do Ribeira participaram do Encontro Nacional de Quilombos, onde foi fundada a Coordenação Nacional de Articulação das Comunidades Negras Rurais Quilombolas (CONAQ), entidade representativa deste segmento em nível nacional.

Para além das organizações e os movimentos que encabeçam, as comunidades quilombolas passaram a compor e participar de outras interfaces de reivindicação política, como o Movimento Negro, a Comissão Pastoral da Terra (CPT), o Partido dos Trabalhadores (PT), o Movimento dos Atingidos por Barragens (MAB), entre outros, conforme pontua a professora Márcia Cristina Américo (2015:57). A organização nesses coletivos

4 No ano 1988, a Companhia Brasileira de Alumínio (CBA) apresentou projeto de construção de quatro UHE no rio Ribeira de Iguape. 
caracteriza a criação e a ocupação de espaços diversos nos diferentes movimentos sociais organizados, visando à luta contra a colonialidade, em defesa dos territórios tradicionais, conforme se consolidam nas comunidades até os dias atuais. Em nível local, cada associação comunitária responde pela organização do território quilombola. Elas, inicialmente, contavam com uma estrutura de organização simples, tendo sob sua incumbência, basicamente, o gerenciamento das contribuições dos associados, mas, mesmo assim, por ser até então desconhecido, o formato de organização causou impactos no modo de vida e cultura local, uma vez que a organização comunitária se dava, anteriormente, exclusivamente em torno de ajutórios, puxirões e outras atividades ligadas à roça (Pasinato 2017:254).

Porém, com o amadurecimento ao longo dos anos, as associações passaram a ter maior visibilidade e discutir questões sociais, políticas e culturais, tornando-se organizações complexas, com a responsabilidade de realizar diferentes funções pela garantia e promoção do desenvolvimento socioeconômico comunitário, aprimorando seus processos de gestão e visando à garantia de transparência, essencial à manutenção dos vínculos familiares centenários existentes no território (Pasinato 2017:265). Hoje, a maioria das associações comunitárias, além da coordenação, possui grupos de trabalho responsáveis pelo gerenciamento de cada segmento ${ }^{5}$. Mesmo as comunidades sendo diferentes entre si, possuindo suas peculiaridades, elas são semelhantes em pelo menos dois pontos fundamentais: na luta pelo território e por direitos, e no modelo de organização em forma de associativismo. Cada associação realiza o gerenciamento do seu respectivo território e as decisões são coletivas, discutidas na Assembleia Geral, constituindo-se como o único órgão deliberativo, pois é formado por todos os associados, moradores do território ${ }^{6}$. Como órgão executivo, a diretoria é geralmente composta por coordenadores geral, financeiro e secretaria, fiscalizados por um conselho, também eleito a cada dois anos, da mesma forma que a coordenação.

A criação da associação é critério exigido para o processo de regularização fundiária, uma vez que o título de domínio e posse do território é

5 A associação é responsável pelo gerenciamento do território. Geralmente, a cada dois anos, são eleitos novos coordenadores e conselheiros fiscais. Conforme a demanda, cada instituição cria seus grupos de trabalho (GT), compostos por duas pessoas; por exemplo, o GT de Turismo é responsável pelo agendamento de grupos, recepção e organização das escalas de trabalho que envolvem a cadeia do turismo. O GT de Educação acompanha todos os processos relativos ao tema dentro e fora da comunidade.

6 Em algumas associações, conforme o estatuto social aprovado pela Assembleia Geral, permite-se a admissão de sócios quilombolas que não estão no território, o que varia de acordo com o entendimento e as determinações de cada comunidade. 
coletivo e expedido em nome dessa instituição jurídica, que, por sua vez, representa determinado território. No entanto, a regularização fundiária das comunidades quilombolas é uma questão que sempre se configurou como objeto de luta política e histórica. O artigo 68 do Ato das Disposições Constitucionais Transitórias (ADCT), da Constituição Federal do Brasil (CF) de 1988, determina o reconhecimento e a titulação dos territórios quilombolas, aliado ao artigo 215, que versa sobre a proteção de tal grupo, bem como ao artigo 216, que determina o tombamento de tais locais (Brasil 1988). Tais dispositivos legais são frutos das demandas de diferentes organizações em diversos espaços, haja vista o movimento negro, o movimento quilombola, entre outros.

Devido à necessidade de representatividade institucional, visando o fortalecimento comunitário contra questões fundiárias que emergiam, com apoio da CUT, do PT e da CPT/Igreja Católica, após várias reuniões envolvendo os moradores do território do Quilombo Pedro, no dia 20 de outubro de 1980, foi fundada a Associação de Bairro de São Pedro, a primeira da região a ser criada com objetivo de defesa dos moradores e do território, tendo já implícita, em seus ideais, a luta pela terra, anteriormente à garantia presente somente mais tarde com a promulgação da Constituição Federal. Logo após, chegaram na região as irmãs pastorinhas Maria Sueli Berlanga e Maria Antonieta Biagioni, que continuam apoiando as comunidades até a atualidade, participando da Equipe de Articulação e Assessoria às Comunidades Negras Rurais do Vale do Ribeira (EAACONE) e do Movimento dos Ameaçados por Barragens (MOAB).

Com a promulgação da Constituição em 1988, o Quilombo Boa Vista, localizado no município de Oriximiná, no Pará, foi a primeira comunidade a dar entrada no processo e pioneira a receber o título de domínio e posse do território, que ocorreu no ano de 1995 (F. Oliveira 2009:169). No Vale do Ribeira, a pedido da Associação Quilombo Ivaporunduva, em 1990, a EAACONE deu suporte para contratação de técnicos especializados ${ }^{7}$, visando à demarcação para a titulação do território dessa comunidade (F. Oliveira 2009:139), ocorrida somente após quase 20 anos, em 2008, através de decisão judicial (Tomazela 2008). Em outros casos, as associações de bairro já existentes, além de passarem a adequar o nome institucional ao novo dispositivo, também buscaram apoio para a garantia do direito ao território. No caso da Associação dos Moradores do Bairro São Pedro,

7 Embora a EAACONE oficialmente fosse instituída somente no ano de 1995, antes ela já existia, mas sem a nomenclatura atual. Tal organização deu suporte para contratação do antropólogo negro Guilherme dos Santos Barboza, engajado no movimento negro e no movimento social, para realização do laudo antropológico para reconhecimento da comunidade (Américo 2015:103; F. Oliveira 2009:139). 
existente desde 1980, passou a atender legalmente por Associação dos Remanescentes de Quilombo de São Pedro e obteve o título parcial do território somente no ano $2001^{8}$, carecendo, ainda, da titulação das áreas que estavam em mãos de grileiros.

Pensando nas instituições de articulação que atuam também fora dos territórios, o MOAB assume a frente contra a construção de hidrelétricas e, mais recentemente, no ano de 2012, a criação da Cooperativa dos Agricultores Quilombolas do Vale do Ribeira (COOPERQUIVALE) (Pasinato 2017:272) propiciou a venda direta de produtos sem atravessadores. A instituição abrange produtores e produtoras quilombolas de comunidades localizadas nos municípios paulistas Itaóca, Iporanga, Eldorado e Jacupiranga. Com objetivo do escoamento da produção convencional e principalmente orgânica para o mercado, este último tem se tornado um real incentivo às roças tradicionais, pois, antigamente, o excedente era descartado ${ }^{9}$ e hoje atende instituições filantrópicas e educacionais, através de programas governamentais ${ }^{10}$, como o Programa de Aquisição de Alimentos (PAA) e o Programa Nacional de Alimentação Escolar (PNAE), propiciando alimentação saudável, livre de agrotóxicos e defensivos à mesa de muitos.

Em nível nacional, no rol dos movimentos de grande importância para a mobilização e articulação das comunidades quilombolas, destaca-se a Coordenação de Articulação das Comunidades Negras Rurais Quilombolas (CONAQ), entidade representativa, organizada através de coordenações ou federações estaduais e regionais, cujos objetivos são:

lutar pela garantia de uso coletivo do
território, pela implantação de projetos
de desenvolvimento sustentável, pela
implementação de políticas públicas
levando em consideração a organização
das comunidades de quilombo; por
educação de qualidade e coerente com
o modo de viver nos quilombos; o
protagonismo e autonomia das mulheres
quilombolas; pela permanência do(a)
jovem no quilombo e acima de tudo pelo
uso comum do Território, dos recursos
naturais e em harmonia com o meio
ambiente (CONAQ s/d).

Esses objetivos são pautados nos diferentes modos de vida das diversas comunidades

8 No dia 15 de janeiro de 2001, foi outorgado o título de domínio de 4.558,1986 ha em nome da associação, não correspondendo à totalidade, desconsiderando áreas particulares que ainda estavam ocupadas por não quilombolas, que ainda eram ameaça. Somente após 15 anos, o território foi totalmente reconhecido pelo INCRA, através da Superintendência Regional de São Paulo, pela Portaria INCRA/P/nº 007, de 24 de março de 2016.

9 Antes da cooperativa, era comum, em diversas comunidades, a presença de atravessadores, que pagavam preços baixíssimos pelos produtos de qualidade, para revenda com valor agregado. Com a venda direta, tal fato diminuiu consideravelmente.

10 Segundo constatam alguns produtores, desde sua criação, a COOPERQUIVALE já firmou contratos com diversos municípios paulistas para entrega de alimentação para escolas, lares de idosos, lares de crianças, entre outros, nas cidades de Jandira, Embu das Artes, Eldorado, Iporanga, São Paulo, Santos e Santo André. 
brasileiras, em diferentes contextos, com foco comum na garantia do direito territorial, visando à implementação de outras políticas públicas. Nesse sentido, o território é a base para demais realizações que são essenciais à manutenção da vida.

A CONAQ foi fundada no ano de 2015 , no I Encontro Nacional das Comunidades Negras Rurais Quilombolas, realizado durante a Marcha Zumbi dos Palmares, em Brasília. No entanto, alguns estados já possuíam significativos históricos de articulação e mobilização, como Maranhão, Pará, Bahia e São Paulo $^{11}$. A luta desse movimento, que pode ser considerado contra-hegemônico, é caracterizada também em prol do ato de existir "enquanto grupo específico ameaçado pelo avanço da especulação imobiliária, dos grandes empreendimentos, que afetam diretamente a existência desses grupos" (CONAQ s/d). Por isso, o conceito de resistência consiste num processo que é histórico, mas contínuo, necessário para a sobrevivência.

Na visão de Boaventura de Sousa Santos (2002:266), "o movimento da globalização contrahegemônica revela a cada vez maior visibilidade e diversidade das práticas sociais que, nos mais diversos cantos do globo, resistem à globalização neoliberal”. O autor denomina isso de constelação de movimentos, pois são muito diversificados. Por um lado, se organizam localmente, sendo diversos em suas práticas, objetivos e pautados em diferentes culturas e, por outro, constituem "organizações transnacionais, umas originárias do Sul, outras do Norte, igualmente muito diversas entre si” (B. Santos 2002:266). Dessa forma, a CONAQ se constitui como uma das principais organizações de reinvindicação dos territórios e outros direitos junto aos órgãos governamentais em nível nacional, estadual e, em alguns casos, municipal, apoiada e integrada a outros movimentos sociais e instituições em prol da vida em territórios coletivos.

As mobilizações do movimento quilombola e apoiadores pela garantia de direitos nos dispositivos legais nem sempre significam a efetividade deles, uma vez que as titulações dos territórios, por exemplo, sempre foram representadas como entrave para os governos estatal-empresariais (Dutra 2011:20). Em 2003, o partido político Democratas (DEM), antigo Partido da Frente Liberal (PFL), impetrou a Ação Direta de Inconstitucionalidade (ADIN) 3.239 no Supremo Tribunal Federal (STF), questionando a constitucionalidade do Decreto 4.887/03, que, por sua vez, regulamenta o artigo 68 da Constituição Federal. No entanto, somente após uma década e meia, o conteúdo foi declarado como constitucional 
pela Suprema Corte brasileira ${ }^{12}$, com a mobilização dos movimentos quilombola e negro, instituições parceiras e sociedade civil. A morosidade no julgamento da ação por parte do poder judiciário ocasionou certa insegurança e recorrentes ameaças às comunidades em seus territórios, tornando-as mais vulneráveis à especulação imobiliária e à ocupação indevida das terras por não quilombolas. Além disso, tal tentativa de negação de um direito fundamental dos povos quilombolas, capitaneada por um partido político e apoiada por muitos outros segmentos da sociedade, demonstra que, mesmo dentro das estruturas que deveriam defender o interesse de todas e todos, sem distinção, encontram-se explícitas as ações do ideal capitalista/colonial, que vê o território diferentemente da ótica das comunidades, forjando um processo de invisibilização e soterramento desses povos, como vem ocorrendo nos últimos anos no cenário político atual, através de diversas tentativas de subtração de direitos dos povos e das comunidades tradicionais e outras minorias, sob a égide da contenção de gastos públicos.

Segundo o filósofo Enrique Dussel (2016), a centralidade e a hegemonização de poder, pautado no capital, que perpassa também os estudos da área da filosofia, são originárias da invasão da América em 1492, quando impetrava-se a ideia de divisão do mundo entre cultura imperial e cultura periférica, que, mais tarde, se perpetuou com a divisão entre "centro", composto pela Europa e Estados Unidos, e "periferia", compreendendo os povos da América Latina, África, Ásia e Europa Oriental (Dussel 2016:51). No contexto territorial quilombola, não é um acaso somente 116 títulos $^{13}$ de terra terem sido emitidos a 217 comunidades ${ }^{14}$, num universo de mais 6 mil comunidades ${ }^{15}$, demonstrando o racismo presente dentro da estrutura governamental, fundante do capitalismo/ colonialismo e que é, portanto, estrutural, não

12 Por maioria de votos, o STF declarou a validade do Decreto 4.887/2003, garantindo, com isso, a titulação das terras ocupadas por remanescentes das comunidades quilombolas. A decisão foi tomada na sessão do dia 08 de fevereiro de 2018, no julgamento da Ação Direta de Inconstitucionalidade (ADI) 3.239, julgada improcedente por oito ministros (STF 2018).

13 De acordo com dados do INCRA, foram expedidos apenas 116 títulos de terras, de um total de 3.000 comunidades reconhecidas oficialmente pelo Estado brasileiro, num universo estimado em 6.000 comunidades existentes no território nacional (CONAQ \& Terra de Direitos 2018:135).

14 De acordo com dados do INCRA, até agora foram 154 títulos emitidos, regularizando 1.007.827,8730 hectares em benefício de 127 territórios, 217 comunidades e 13.145 famílias quilombolas (as áreas foram tituladas pelo INCRA, FCP, FCP/ITERBA/CDA-BA, ITERPA, ITERMA, ITESP e SEHAF-RF, INTERPI/INCRA, SPU, IDATERRA-MS e ITERJ) (INCRA s/d).

15 Ver as duas notas anteriores. Ambas apresentam dados do INCRA, no entanto, mesmo havendo discrepância neles, o foco é demonstrar a demora no processo de reconhecimento e regularização fundiária em relação às comunidades quilombolas. 
estando dissociado de um projeto político que visa condições socioeconômicas específicas, segundo o jurista Silvio Luiz de Almeida (2018). Segundo ele,

O conceito de racismo institucional foi enorme avanço no que se refere ao estudo das relações raciais. Primeiro, ao demonstrar que transcende o âmbito da ação individual, e, segundo, ao frisar a dimensão do poder como elemento constitutivo das relações raciais, mas não somente o poder de um indivíduo de uma raça sobre outro, mas de um grupo sobre outro, algo possível quando há controle direto ou indireto de determinados grupos sobre o aparato institucional (S. Almeida 2018:36)

O controle sobre as instituições governamentais é evidenciado na história do Brasil em diferentes momentos de ausências de políticas públicas a variados segmentos da sociedade, haja vista a morosidade de ações reparatórias pós-abolição da escravização de negros e negras no país e a morosidade na regularização de territórios indígenas, entre outras. Ao considerar que o racismo transcende as relações individuais, alicerçando a dominação de povos juntamente ao capitalismo/ colonialidade, os ataques às comunidades tradicionais se estendem por toda a América Latina e demais países do mundo, empobrecidos pelo processo de expropriação colonial. As pressões e ameaças sofridas historicamente pelas comunidades em seus territórios no Brasil e em outras regiões se dão por diversos interesses, que vão desde a construção de barragens, extração ilegal de madeira, construção de hotéis de luxo e, principalmente, pela mineração e produção de agrocombustíveis (Escobar 2015:28). Dessa forma, evidenciamos "uma verdadeira guerra contra os mundos relacionais, $\mathrm{e}$ mais uma tentativa de desmantelar tudo o que é coletivo" (Escobar 2015:29). Como consequência da não demarcação das terras, a violência no campo se faz presente. No ano de 2017, com um total de 14 assassinatos de lideranças quilombolas, o Brasil alcançou o maior índice dos últimos dez anos ${ }^{16}$. Uma marca que não deve ser motivo de orgulho, mas que explicita a intolerância às diferentes proposituras de sociedade que tais comunidades vislumbram e defendem.

A criação dos movimentos quilombolas tem como foco principal a defesa do território coletivo, no entanto, para isso, as lutas assumem várias frentes nas áreas ambiental, de saúde, lazer, acesso ao mercado, educação, entre outras. A defesa de tal território é antagônica ao sistema capitalista global. Para Walter Mignolo (2007), "hoje se busca a descolonização do saber e da subjetividade, mediante elaboração de alternativas ao capitalismo e ao Estado moderno e sua dependência do poder

16 O ano de 2017, último em que o levantamento foi realizado, apresentou-se como o mais violento para as lideranças quilombolas, somando um total de 18 assassinatos, apontando crescimento de $350 \%$ em relação ao ano anterior, segundo mapeamento realizado pela CONAQ \& Terra de Direitos (2018:46). 
militar, mediante a criação de novas ideologias” (Mignolo 2007:108). Nesse sentido, é possível pressupor que as comunidades quilombolas do Vale do Ribeira têm em sua essência essa busca da descolonização do saber e subjetividade quando mantêm vivas as sementes crioulas, continuam a fazer a roça de coivara e os puxirões, retomam os territórios ancestrais ocupados por não quilombolas, permitindo que a floresta se regenere e, principalmente, quando se organizam em movimentos sociais, pela defesa da terra.

\section{EXPROPRIAÇÃO DE TERRAS QUILOMBOLAS} E A ATUAÇÃO DOS MOVIMENTOS DE DEFESA

O histórico de ocupação dos territórios pelas comunidades quilombolas localizadas às margens do rio Ribeira de Iguape, entre os municípios de Eldorado e Iporanga, no estado de São Paulo, nos remete ao início do século XVII, quando os primeiros colonizadores chegaram ao que hoje é conhecido como Quilombo Ivaporunduva, trazendo com eles pessoas do continente africano escravizadas para a extração de ouro de aluvião (Barboza 1992; Krug 1912; Stucchi et al. 1998). Somente há registros do surgimento das comunidades quilombolas vizinhas nas primeiras décadas do século XIX.

Roza Machado e Bernardo Furquim são os primeiros nomes lembrados na região por registrarem o território de São Pedro, denominado "Sítio", no Livro de Terras da Paróquia de Xiririca, no ano de 1856 (Berlanga 2017:221), após os já estabelecidos quilombos Ivaporunduva, Pedro Cubas e Abobral. Parte dos descendentes do casal se espalharam e juntaram-se àqueles que já se estabeleciam pelas diversas comunidades do entorno, como Sapatú, Pilões, André Lopes, Nhunguara, Ivaporunduva, entre outras (Américo 2015; Carvalho 2006; T. Andrade et al. 2000; ITESP 1998a, 1998b), ou até mesmo habitando locais que posteriormente se tornariam esses novos quilombos. Muitos permaneceram no Território do Quilombo São Pedro, ocupando as diversas "vilas" e constituindo famílias. Esse processo é recorrente, desde a ocupação de São Pedro, ainda sendo hoje cultivadas as relações de amizade, parentesco, casamentos e compadrio.

O Vale do Ribeira, que se destacara no cenário aurífero e rizicultor, permaneceu sem muita visibilidade por alguns anos, e as políticas públicas nem sempre chegavam às populações mais afastadas dos centros urbanos. O acesso a escolas, por exemplo, não era fato para as comunidades quilombolas (Américo 2015:212). A partir da década de 1930, do século XX, com foco na expansão agrícola na região, o governo do estado estimulou a produção da monocultura, oferecendo estímulos aos bananicultores (Queiroz 2006:55), e ampliou a linha ferroviária que ligava 
parte do Vale até Santos, estendendo-a até Registro e passando por mais cinco cidades (Carril 1995:123). No final da década de 1950, a abertura da rodovia Régis Bittencourt ${ }^{17}$ propiciou maior acesso à região, ligando as cidades de Curitiba, Paraná, e São Paulo, São Paulo, ao Vale. E mais tarde, no ano de 1969, concluiu-se a rodovia que liga Eldorado a Iporanga (Paes 2007:103), que dá acesso a várias comunidades quilombolas ${ }^{18}$ dos dois municípios. Essa expansão do capitalismo provocada pelo Estado no Vale do Ribeira, através de bancos estatais e de secretarias de estado financiando infraestrutura, também propiciou investimentos em áreas de produção, tornando camponeses e pequenos proprietários subordinados (Carril 1995:108) ao capital e atraiu muitos interesses, inclusive em terras ocupadas pelas comunidades quilombolas, que não conseguiam acessar os estímulos oficiais.

No fim da década de 1960, São Pedro e Galvão ainda formavam uma única comunidade, por possuírem um mesmo tronco familiar e, portanto, o mesmo histórico de formação. Por isso, para este artigo, o termo Território do Quilombo São
Pedro será usado para referenciar tal espaço, que, hoje, engloba duas comunidades, localizadas em área de vegetação totalmente fechada e de difícil acesso. Assim, com a valorização das terras pelo facilitado acesso através das rodovias e estímulos promovidos pelo governo para desenvolvimento da região, anúncios de venda de propriedades circularam em jornais da capital paulista. Segundo Maria Celina Pereira de Carvalho (2006), o Sítio Tiatan $^{19}$, que compunha o território supracitado, pertencia a Roza Machado e Perpétua, duas das esposas de Bernardo Furquim. A autora aponta a possibilidade de Perpétua ter vendido, ainda no início do século XX, uma parte do local a Juvenal Maciel, originário do bairro vizinho não quilombola, Castelhano. Mesmo após os Maciel terem contraído matrimônio com descendentes de Bernardo Furquim e convivido na área, alguns descendentes de Juvenal Maciel tentaram demarcar para si a totalidade do local, quando "os engenheiros estavam medindo as terras para conceder a permissão de uso" (Carvalho 2006:93) ${ }^{20}$.

17 Inaugurada no ano de 1961, a Régis Bittencourt é a rodovia federal que liga os estados de São Paulo e Paraná, se estendendo até a divisa de Santa Catarina (Rodovia Régis Bittencourt s/d). Ela corta algumas cidades do Vale do Ribeira, passando por Jacupiranga, um dos acessos aos municípios de Eldorado e Iporanga.

18 Estão localizados à margem da rodovia Eldorado/Iporanga os quilombos Sapatú, André Lopes e Piririca. As comunidades quilombolas São Pedro, Pilões, Maria Rosa, Nhunguara e Pedro Cubas localizam-se mata adentro, distantes da via.

19 Localizado entre o Quilombo São Pedro e o Quilombo Galvão, hoje pertence à área da segunda comunidade, mas antigamente formavam um só território.

20 Pressuponho que o termo se refere à Lei no 3.962, de 24 de julho de 1957, que dispunha sobre o processamento das legitimações de posse em terras devolutas (São Paulo 1957). 
Ao não terem suas solicitações atendidas, os descendentes de Juvenal Maciel, então, resolveram vender as terras, anunciando-as em jornais de São Paulo (Carvalho 2006:93). Esse processo que iniciou conflituoso, mais tarde, teve desdobramentos, ocasionando assassinato de uma liderança e sérias ameaças a moradores.

Francisco Tibúrcio do Nascimento, no ano de 1976, comprou as terras postas à venda. Adquiriu legalmente 60 alqueires, mas chegou a ocupar um total de 1.552 ha, entre os atualmente identificados como área dos quilombos São Pedro e Galvão, conforme pontua Maria Sueli Berlanga (2017). Segundo a autora, o homem era truculento, derrubava cercas e fornecia armas aos jagunços, além de queimar casas dos moradores, deixava o gado invadir as plantações, ameaçando os locais com armas de fogo, sendo os moradores pressionados a deixarem suas terras (Berlanga 2017:226). Esse processo passou a causar medo nos residentes dos dois territórios, que comumente viviam e trocavam dias de serviço, visitas e alimentos. Em algumas vezes, alguns jovens iam trabalhar para o fazendeiro para ganhar algum dinheiro, plantando bananas. No entanto, prevaleciam táticas para dificultar a permanência deles na região, tanto terrenas quanto míticas/ espirituais (Carvalho 2006) ${ }^{21}$. Os trabalhadores chegavam a enterrar várias mudas em buracos de tatu ou plantavam até dez unidades em uma só cova, quando o correto é se plantar somente uma. O bananal nunca saiu dos planos, mas os conflitos em torno da terra permaneciam e ocasionaram o assassinato da liderança Carlos da Silva, no dia 03 de julho de 1983, por ser contra a tentativa de invasão das terras quilombolas (Berlanga 2017:226), o que causou comoção, medo em toda a comunidade, por se tratar de uma prática raríssima, que muitas pessoas nunca haviam presenciado ou ouvido no Território do Quilombo São Pedro, porém despertara ainda mais o espírito de união pela defesa do local ancestral.

O assassinato de Carlos da Silva ocorre em um contexto de reinvindicações de direitos. Conforme nos mostra Frederico Menino Bindi de Oliveira (2009), ao estudar, a partir da EAACONE, o histórico de organização do movimento quilombola no Vale do Ribeira pela reivindicação de direitos, as décadas de 1970 e 1980 foram de grande instabilidade na região, demonstrada pela elevação dos índices de violência no campo, pelo endurecimento de leis ambientais, pela ausência de oportunidades e pela falta de entendimento da realidade das comunidades rurais para a

21 No escrito de Carvalho (2006:145), um dos entrevistados quilombolas relata sobre trabalhos de feitiçaria executados como forma de contra-ataque aos feitiços realizados pelo fazendeiro interessado no território quilombola. 
implementação de políticas públicas. Essa soma de fatores fez com que muitos abandonassem seus locais de origem, enfraquecendo os territórios e indo buscar oportunidades em cidades das regiões da Baixada Santista e São Paulo.

Em outro caso, o fazendeiro Amadeu Bruning adquiriu uma pequena área, mas construiu cercas sobre um espaço maior, inclusive deixando o gado livre para adentrar as roças dos moradores, dandolhes prejuízos. O fazendeiro se apossou ilegalmente de vasta área já ocupada por Bernardo Furquim e Roza Machado, a Vargem, chegando a ter mil cabeças de gado, que poluíam as águas do $\mathrm{rio}^{22}$, impossibilitando os quilombolas de Ivaporunduva de consumir a água ou peixes. Funcionários portavam armas de fogo o tempo todo, inclusive nas xibocas ${ }^{23}$, algo incomum na localidade, onde as pessoas andavam com o facão na cintura, mas, em qualquer estabelecimento comercial, religioso ou residencial, deixavam o utensílio do lado de fora, em sinal de respeito, ao adentrar.

A criação de unidades de conservação na região (Carvalho 2006; Hayama 2017; Carril 1995;
Diegues 2007) e a efetivação de leis que proibiam as comunidades de fazerem as roças do modo tradicional - as roças de coivara - obrigaram as comunidades a extraírem o palmito juçara ${ }^{24}$ clandestinamente, para venda a compradores externos que negociavam o produto, proibido pelo Código Florestal ${ }^{25}$. Isso aliado à insegurança alimentar, às ameaças sofridas no território, ocasionadas por ocupantes ilegais da terra, a cada dia, mais famílias saíam em busca de outras oportunidades, ocupando as periferias de grandes cidades da Grande São Paulo e da Baixada Santista.

Não é possível afirmar se por coincidência ou acordo entre grileiro e prefeito, nos primeiros anos da década de 1990, a prefeitura do município de Eldorado resolveu reformar a balsa, que era o único meio de acesso de veículos entre a rodovia e as comunidades São Pedro, Galvão e Ivaporunduva. Foram oito meses de travessia de canoa, tempo suficiente para os funcionários, a mando do invasor, destruírem mais de 250 hectares da Mata Atlântica, transformando-a em pasto para o gado. A fiscalização dificilmente cruzaria o rio de canoa para se deslocar a pé por 13

22 O rio das Vargens nasce no Território do Quilombo São Pedro e no Quilombo Ivaporunduva, passando a se chamar rio Bocó.

23 Xiboca ou boteco é o nome comumente usado para designar bar.

24 Juçara (Euterpe edulis), em alguns locais da região conhecida como jiçara, é o nome da palmeira de onde se extrai o palmito. Espécie que era comum na Mata Atlântica, hoje é escassa, devido à falta de manejo, à extração descontrolada e à ausência de fiscalização, principalmente nas décadas dos anos 1980 aos anos 2000 em diferentes locais do Vale do Ribeira.

25 A Lei n 4.771/1965, do Código Florestal, foi alterada pela Lei nº 12.6151/2012, instituindo o novo Código Florestal. 
km até o local. Na visão de boa parte da comunidade, esse não é o tipo de ação que podemos chamar de coincidência, pois havia necessidade por parte do grileiro de ampliação da área e houve demora na reforma da balsa, transparecendo um acordo entre o particular/privado e o público.

Antônio Carlos Sant'Ana Diegues (2007), ao relacionar a expropriação territorial como consequências da abertura das rodovias na região do Vale do Ribeira, pontua que grupos de grileiros e imobiliários se apossaram de praias e sítios, expulsaram povos tradicionais e ampliaram o desmatamento, operando serrarias e indústrias de palmito (Diegues 2007:27), sendo essas últimas abastecidas por palmiteiros quilombolas ${ }^{26}$, logrados pelos atravessadores ${ }^{27} \mathrm{e}$ donos de indústrias, que pagavam valores muito baixos pelos produtos, obtendo lucros altíssimos. Essa atividade, mesmo ilegal, e parecendo ser uma alternativa à roça, que estava proibida, perdurou até a quase extinção da espécie, devido à massiva invasão de não quilombolas nos territórios, que somente se encerrou após lideranças das comunidades exigirem providências dos órgãos competentes.

No caso do grileiro, após mais de uma década de devastação da Mata Atlântica e diversas afrontas às comunidades, representantes da Associação dos Remanescentes de Quilombo de São Pedro ${ }^{28}$ denunciaram os fatos ao Governo do Estado, que designou uma comissão para averiguação das denúncias, culminando na desapropriação ${ }^{29}$ da área. Dessa forma, observa-se, tanto neste, quanto no caso do Sítio Tiatan, as diferentes concepções de relação com o território tidas pelas comunidades e pelos grileiros. Quando se observa os diferentes sentidos que diversas sociedades atribuem às "suas bases materiais, abre-se espaços para a percepção e a denúncia de que o ambiente de certos sujeitos

26 Entre as décadas de 1960 e 1980, era comum muitos palmiteiros de fora adentrarem o território, como se estivessem em uma terra sem leis, invadindo casas, sacando alimentos, sem nenhum medo ou receio. Não fossem as invasões em massa, até hoje, utilizando-se do manejo, as comunidades quilombolas vizinhas São Pedro, Galvão, Ivaporunduva, Pedro Cubas, Galvão, Maria Rosa e Pilões teriam possibilidade de explorar juçara (palmito e semente) para complementação de renda.

27 Atravessador é o indivíduo que se interpõe entre o produtor e o vendedor, negociando um produto que não é seu, comprando-o por um preço baixo e revendendo-o por um valor elevado, obtendo lucro, sem ter produzido.

28 Antes mesmo da promulgação da Constituição Federal de 1988, as comunidades já eram identificadas como comunidades negras, com seus históricos de formação e ocupação dos territórios ligados à ancestralidade negra africana, advinda da escravização de negros e negras no Brasil colonial. Após a referida lei, várias associações foram criadas, visando a reivindicação dos territórios coletivos, conforme prevê o dispositivo legal, bem como as associações já existentes que passaram por adequações de nomenclatura, inserindo o termo "quilombo".

29 Posteriormente à desapropriação realizada pela Fundação Instituto de Terras do Estado de São Paulo José Gomes da Silva (ITESP) e pela Fazenda do Estado de São Paulo, o fazendeiro entrou com recurso no Tribunal de Justiça de São Paulo, tentando reaver a área, tendo sido negada a apelação, conforme consta na decisão do desembargador relator Ferreira Rodrigues, no Acórdão sob Registro 2015.0000277817, da $4^{\mathrm{a}}$ Câmara de Direito Público do Tribunal de Justiça de São Paulo, em resposta à Apelação nº 0265232-63.2009.8.26.0000. 
prevaleça sobre o de outros, fazendo surgir o que se veio denominar 'conflitos ambientais"” (Acselrad 2010:108). Se, de um lado, havia a força da união comunitária, através da associação, defendendo o território, de outro, um "infrator do ambiente", que se "utilizando de má-fé, construiu imóveis contrariando as normas ambientais" ${ }^{\prime 30}$, prejudicando e ameaçando o modo de vida dos originários do local. Esse processo de articulação e resistência às opressões das comunidades quilombolas do Vale do Ribeira, através de suas associações, apoiadas por instituições parceiras e outros movimentos sociais, pauta-se na luta por direitos sociais territoriais, que envolve o combate ao racismo ambiental, tendo suas reivindicações voltadas ao ecologismo combativo, buscando justiça ambiental, envolvendo-se nas discussões críticas e inserindo-se progressivamente no campo do ecologismo combativo (Acselrad 2010:107). Contraditórias à apropriação privada dos recursos naturais que são comuns a todos e todas (Alier 2007), as associações quilombolas do Vale do Ribeira contribuem para a promoção do surgimento do "ecologismo dos pobres, ecologismo popular, a ecologia da sobrevivência e do sustento, a ecologia da libertação e movimento pela justiça ambiental (local e global)" (Alier 2007:356).

Dessa forma, as ações aqui apresentadas remetem a um encadeamento dos vários elementos presentes no território. São saberes que servem de base para o processo de organização e defesa, oriundos da observação, da coletividade, das práticas diárias na roça, partilhados através da oralidade, ligando o quilombola também às práticas de preservação ambiental e, consequentemente, ao direito de existir plenamente.

\section{AMEAÇA TERRITORIAL: RACISMO AMBIENTAL}

O território quilombola é a base de produção da vida e por ele perpassam as relações sociais/ pessoais, indissociáveis das relações com a fauna e a flora. Por isso, nesse contexto, não há como falar sobre o racismo ambiental de que as comunidades são vítimas, sem relacionar isso ao entendimento e ao significado do território para quem nele habita.

Cunhado pelo reverendo negro americano Benjamim Chavis, que elaborou a expressão para falar das injustiças ambientais cometidas em áreas selecionadas, afetando determinados grupos sociais, naquela situação, os negros (Pacheco 2007), o termo racismo ambiental remete às injustiças ambientais que afetam, desproporcionalmente, etnias que estão em estado de vulnerabilidade; ele "não se configura apenas por meio de ações que tenham uma intenção racista, mas igualmente por meio de ações que tenham impacto racial, não obstante a intenção que lhes tenha dado

30 Palavras do relator da decisão judicial citada na nota anterior. 
origem” (Herculano \& Pacheco 2006:25). Talvez não paramos para pensar sobre o fato de que, mesmo em área de preservação ambiental, a rodovia Régis Bittencourt (BR-116) teve as obras de duplicação autorizadas e executadas, após várias revisões no projeto, visando o menor impacto possível ao ambiente ${ }^{31}$; em contraponto a isso, a comunidade Quilombo Bombas, no município de Iporanga, São Paulo, ocupando há séculos o seu território, nunca pôde abrir uma estrada ou rodovia para acesso ao local. Poucos moradores ainda lá resistem, mas é constante o deslocamento forçado de quilombolas de seu território devido a dois fatores determinantes: primeiro, a ausência de políticas públicas ocasionadas pelo abandono do setor público e, segundo, porque a área para acesso a Bombas foi demarcada, posteriormente ao surgimento da comunidade, como Parque Estadual Turístico do Alto Ribeira (PETAR), proibindo a extração de vegetação nativa. Ao justapor os dois casos, o objetivo não é se posicionar contrariamente à duplicação de uma rodovia, que, por sinal, é de grande importância para o país e para a segurança dos usuários, mas, justamente, é constatar que há tratamento diferenciado na relação humano e natureza nas áreas habitadas por povos e comunidades tradicionais. Ao ser negado o acesso ao Quilombo Bombas, bem como nem serem discutidas possibilidades de execução de uma obra com redução de impactos ambientais, tal qual feita no caso da Régis Bittencourt, constata-se o racismo ambiental, que, neste caso, tem causado o esvaziamento do território, perdas de identidade e da estreita relação com a ancestralidade negra africana.

No Brasil, o debate sobre racismo ambiental contempla a participação da academia, organizações não governamentais e lideranças de alguns movimentos sociais, tendo como importante marco a criação da Rede Brasileira de Justiça Ambiental ${ }^{32}$, no ano de 2001, uma das articulações responsáveis por "um número expressivo de ações, de denúncias e de vitórias, envolvendo a justiça ambiental” (Herculano \& Pacheco 2006:27) no país. Ao certo que antes da Rede, ações similares foram realizadas por outras organizações de atuação local, em diferentes regiões do país, no entanto, a centralização e o

31 O projeto surgiu em 2007, no entanto, a obrigatoriedade de adaptação da obra, visando baixo impacto ambiental, causou demora e necessidade de adequações no projeto. Em 2013, saiu a licença ambiental para o trecho que se sobreporia à área mais preservada de Mata Atlântica. Dois anos mais tarde, o projeto foi readequado e, em 2017, a obra foi concluída, após uma série de exigências envolvendo a preservação ambiental e menor impacto possível (Arteris S/A 2017).

32 A Rede Brasileira de Justiça Ambiental foi criada como uma das principais deliberações do Colóquio Internacional sobre Justiça Ambiental, Trabalho e Cidadania. No ano de 2006, era integrada por 87 entidades, envolvendo em torno de 300 pessoas (Herculano \& Pacheco 2006:27). 
compartilhamento de informações são importantes tanto para a criação de táticas de defesa dos territórios e dos povos que nele habitam, quanto para diagnóstico dos ataques sofridos por esses e demais povos. Em diferentes regiões, comunidades quilombolas, povos indígenas e outras populações tradicionais têm lutado contra grandes empresas quanto à compra ou à posse indevida das terras para o cultivo de eucalipto e a mineração, que tem ocasionado contaminação por manganês e chumbo (Herculano \& Pacheco 2006:27). Dessa forma, mesmo pontuados há quase uma década e meia, os fatos que perpassam pela expropriação dos territórios, o envenenamento de terras e das águas e o uso de violência física contra povos e comunidades tradicionais continuam a ocorrer em diversas regiões do país.

No Vale do Ribeira, a pesquisa da bióloga quilombola Maíra Rodrigues da Silva (2017) sobre o potencial de regeneração de solos afetados por contaminação de chumbo, arsênio e zinco, provenientes da mineração desenvolvida no século passado na região dos municípios de Adrianópolis, Paraná, e Iporanga, São Paulo, evidencia que foram gerados significativos volumes de rejeitos enriquecidos desses metais, sendo diretamente descartados no rio Ribeira de Iguape ou empilhados nas proximidades das estradas vicinais que ligam alguns bairros, causando a contaminação do solo, de águas superficiais (Silva 2017:16) e de humanos, também através dos alimentos cultivados e consumidos, de acordo com estudos da Fundação Oswaldo Cruz (FIOCRUZ 2014). Os materiais são levados pelas constantes cheias do rio Ribeira de Iguape, contaminando as margens e consequentemente os peixes e os alimentos consumidos pela população abaixo, especificamente de bairros como Jurumirim, Castelhanos e Poço Grande, além das comunidades quilombolas Ivaporunduva, André Lopes, Sapatú, São Pedro e Galvão.

São muitos os casos de povos tradicionais afetados por megaprojetos ${ }^{33}$ : “indígenas, quilombolas, ribeirinhos, caiçaras, quebradeiras de coco, entre outras comunidades tradicionais, subalternizadas e inferiorizadas pelo espectro do capitalismo global" (Silva \& Moraes 2019:39). No Vale do Ribeira, foram várias tentativas frustradas de construção de hidrelétricas, o que, talvez, tenha evitado vários crimes/desastres ambientais, diferentemente dos casos de Mariana, Minas Gerais, no ano de 2015, Barcarena, Pará, em 2018, e Brumadinho, Minas Gerais, em 2019; e da construção de Belo Monte, em Altamira,

33 O termo megaprojetos aqui é usado para referir-se a grandes empreendimentos que, na maioria das vezes, causam impactos negativos nas vidas das populações afetadas pela sua implantação. Entre eles, estão hidrelétricas, rodovias, portos, atividades de mineração etc. 
Pará (Silva \& Moraes 2019:39). Nesse sentido, é possível afirmar que, enquanto na visão dos povos tradicionais o fim da natureza seria um suicídio coletivo da humanidade, por outro lado, "a cultura moderna que se globaliza nada aprende a respeito da natureza com outras culturas, aparentemente mais 'primitivas' ou 'atrasadas', de acordo com os parâmetros vigentes de desenvolvimento" (Dussel 2016:70). Há diferenças de compreensão expressando uma dualidade entre sacrifício da natureza e de humanos, visando o capital, versus entendimento e harmonia entre humano e natureza, compondo um único território coletivo.

\section{CRIARAM LEIS PARA PROTEGER A FLORESTA SEM PENSAR EM QUEM PROTEGE A FLORESTA ${ }^{34}$}

A região do Vale do Ribeira estende-se pelos estados de São Paulo e Paraná e abriga diversas Unidades de Conservação, comunidades quilombolas e outros povos e comunidades tradicionais. A criação de áreas protegidas é válida e, em muitos casos, essencial, visando à preservação da natureza. Os povos tradicionais não são opositores a esse tipo de ação, no entanto, não se pode desconsiderar a presença de quem nela há séculos habita e a protege.

Juntamente às ações que visavam o desenvolvimento do Vale do Ribeira, implementadas a partir de meados do século XX (Carril 1995; Queiroz 2006; Paes 2007), também chegaram, na região, atividades que têm causado interferência negativa direta nos diferentes territórios. A maioria desses projetos não chegou às comunidades mais afastadas dos centros urbanos, sendo que ainda hoje estradas são intransitáveis em dias de chuva, causando o isolamento desses povos. Conforme pontuado anteriormente, o início da ocupação por comunidades quilombolas data do século XVII e mais intensamente no início do século XIX (Barboza 1992; ITESP 1998a, 1998b; Stucchi 1998; T. Andrade et al. 2000). E, na contramão do modo de vida já existente, principalmente a partir da década de 1960, com apoio de "organizações da sociedade civil (ONG), cientistas, movimentos e associações locais" (Diegues 2007:31), foram criadas áreas de proteção na região, muitas delas sobrepostas aos territórios comunitários coletivos, já existentes há séculos.

No ano de 1958, foi criado o Parque Estadual Turístico do Alto Ribeira (PETAR), cuja delimitação se sobrepunha ao território do Quilombo Bombas, conforme pontua a professora Maria Walburga dos Santos (2010:150). Até os dias atuais, os poucos moradores não têm ainda acesso a direitos sociais essenciais, como energia elétrica, água encanada

34 Baseado em trecho do livro "Roça é vida” (Luiz et al. 2020). 
ou estradas. Neste caso, há a atuação de um parque protegendo a natureza, sem considerar as pessoas que há séculos a preservam.

Andrew Toshio Hayama (2017) faz um panorama sobre as sobreposições de unidades de conservação em comunidades quilombolas do Vale do Ribeira. Entre o final da década de 1960 e o ano de 2001, diversas comunidades registraram isso em seus territórios. Em um dos últimos casos, o da sobreposição do Parque Estadual Intervales às comunidades de São Pedro, Maria Rosa, Pilões, Pedro Cubas e Ivaporunduva, em 1995, só houve recuo no ano de 2001, com a Lei Estadual $n^{\circ}$ 10.850 (Hayama 2017:118), oriunda da pressão das associações locais e instituições parceiras. Nesse intuito, a luta que era pela regularização dos territórios perpassa também pelo enfrentamento ao racismo ambiental.

A mobilização por justiça ambiental não desqualifica a reivindicação territorial. Concordando com o antropólogo Alfredo Wagner Berno de Almeida e colaboradores (2011), "não é porque as titulações não acontecem, que as comunidades deixam formalmente de existir. $\mathrm{O}$ que não acontece também existe magicamente como fato social" (A. Almeida et al. 2011:13). Isso implica a ideia de que o foco é pela garantia do território, no entanto, se ele não é regularizado, as frentes de reivindicação se voltam também para as demais necessidades imbricadas nele, como demandas por melhorias no sistema educacional, valorização cultural, acesso, segurança alimentar e outros. Mesmo quando há a demarcação e registro, outros fatores são necessários para a manutenção desse espaço, visando à gestão dele e garantindo a vida de gerações futuras.

No bojo das reivindicações, o fortalecimento das organizações locais levou o governo do estado a editar dispositivos legais, atribuindo ao ITESP não só a incumbência do reconhecimento de comunidades quilombolas, como também a resolução de conflitos procedentes da imposição de Unidades de Conservação nos territórios (Silveira 2003:29). Trata-se de um marco importante na história do processo de reivindicação do território, pois só ao pautar-se na organização comunitária, os direitos coletivos passaram a entrar na pauta governamental.

Em todos os casos de racismo ambiental apresentados, está presente a criação, especialmente por parte do governo do estado, de um modelo de preservação que afeta diretamente o modo de vida quilombola. No caso dos procedimentos de licenciamento das roças tradicionais, diversos entraves têm sido vivenciados pelas comunidades desde a criação das unidades de conservação $0^{35}$. Os 
aproximadamente 30 anos foram tempo suficiente para causar danos quase irreversíveis, afetando as danças, as trocas de dia e relações de compadrio, a salvaguarda das sementes, a segurança alimentar, a organização comunitária, os modos de fazer, permeados pelos saberes que envolvem cada atividade. Talvez, essa tentativa de aniquilamento tenha sido uma das ações mais cruéis, pois, ao impactar negativamente a roça, também se soterram todos as demais manifestações a ela ligadas, bem como as gerações futuras não mais se habituam à valorização desse tipo de trabalho (Pedroso Junior 2008:101) e modo de vida que lhes fora negado.

Allan da Silva Coelho (2014) pondera que, no sistema capitalista, a vida futura é garantida pelo sacrifício humano, que, por sua vez, consiste na expropriação e destruição da natureza, compreendido como um "sacrifício fértil, portanto necessário e justificado” (Coelho 2014:245). Há um paradoxo no que tange às relações com a natureza. Nesse entendimento, pode-se sacrificar as comunidades quilombolas e outros povos tradicionais para manter o meio ambiente sem gente, mas, por outro lado, durante 30 anos a região viveu sob ameaça de construções de usinas hidrelétricas. De um lado, não se pode fazer as roças de coivara, mas são liberadas licenças para exploração de minérios. E, por fim, enquanto há algumas décadas, as leis ambientais proibiam, além das atividades agrícolas, a extração de materiais necessários, como cipós e taboa, usados nos utensílios domésticos, e madeira para fazer as casas; hoje, a legislação foi flexibilizada para beneficiar a iniciativa privada. Através da Lei $\mathrm{n}^{\circ}$ 16.260/2016, o Governo do Estado de São Paulo, sem consulta prévia às comunidades impactadas, conforme prevê a Convenção 169 da Organização Internacional do Trabalho (OIT), autorizou a concessão de 25 unidades de conservação, em que serão permitidas, entre outras atividades, a exploração comercial madeireira e subprodutos florestais ${ }^{36}$. Entre a lista, estão parques em que não eram permitidas atividades relacionadas ao modo de vida tradicional quilombola, mas que agora poderão ser explorados pela iniciativa privada.

O mito de uma natureza intocável e intocada, baseado em movimentos conservacionistas norteamericanos visando salvar a natureza dos efeitos do desenvolvimento urbano e industrial, aponta como negativa qualquer interferência humana, impossibilitando a relação natureza e cultura tradicional (Diegues 2001:37). No entanto, a questão a ser pensada é sobre quais seres humanos

36 De acordo com a Lei $\mathrm{n}^{\circ}$ 16.260, de 20 de junho de 2016, são subprodutos florestais: madeira serrada de qualquer forma, resíduos da indústria madeireira, dormentes, postes, carvão, carvão vegetal nativo e xaxim. 
estão inseridos nesses territórios e como eles se relacionam com a natureza, ao ponto de a manterem intacta e preservada, diferentemente de muitos outros grupos sociais. Nesse intuito, não que as comunidades não tenham muito o que aprender, mas elas têm também muito a ensinar.

\section{REFLEXÕES FINAIS}

Desde os primeiros africanos trazidos para o Brasil, no período da escravização, a resistência pelos direitos sociais é inerente a tal povo. A formação de quilombos por diversos motivos, como a fuga, compra de terras ou doação, foi um dos primeiros atos de não aceitação ao sistema imposto. No período pós-abolição, movimentos de defesa continuaram e têm permanecido no enfrentamento aos diversos ataques sofridos, e o processo de organização e reivindicação de inclusão de direitos territoriais assegurados na Constituição Federal de 1988 é, sem dúvida, um dos atos institucionais mais marcantes do povo negro quilombola em relação à segurança nos dispositivos legais.

No contexto do Vale do Ribeira, a Associação Quilombo São Pedro se apresenta como pioneira, ao criar uma associação de bairro, visando a defesa do território. Em seguida, as demais comunidades iniciaram seu processo de organização em formato de associação, visando a solicitação de reconhecimento e titulação das terras. A criação da EAACONE e do MOAB, com a participação de povos e comunidades tradicionais, e a sua inserção em movimentos sociais em âmbito nacional, como o movimento negro e a criação da CONAQ, foram também necessárias para a defesa do território. Da mesma forma, aliadas a essa luta, as comunidades compõem os movimentos de embate às políticas ambientais excludentes, também pela garantia do direito de fazer a roça do modo tradicional quilombola, visando à segurança alimentar. A criação da COOPERQUIVALE, a campanha "Tá na hora da roça" ${ }^{37}$, o processo de reconhecimento da roça de coivara como patrimônio cultural imaterial do Brasil, chancelado pelo IPHAN, e a realização de "Acordos voluntários para o desenvolvimento de atividades tradicionais sustentáveis" ${ }^{\prime 8}$ com a Secretaria Estadual de Meio Ambiente garantem a continuidade da roça de coivara, visando não só a sobrevivência/permanência no território, mas, principalmente, a manutenção da vida de todos os que nele habitam.

Em meio a avanços, afrontas ainda persistem

37 Para mais informações sobre a campanha, ver ISA (s/d).

38 A Resolução SMA nº 189, de 20 de dezembro de 2018, estabelece os critérios e procedimentos para as atividades de exploração sustentável de espécies nativas do Brasil no estado de São Paulo e categoriza a roça de coivara quilombola como atividade tradicional sustentável. 
e têm sido recorrentes, pautadas em políticas excludentes, que colocam em risco os territórios coletivos. A ausência de políticas públicas de acesso, saúde, geração de renda e educação, aliada à morosidade do Estado no reconhecimento e na titulação das comunidades quilombolas, historicamente tem ocasionado êxodo rural, violência no campo, incluindo assassinatos de lideranças, além de afrontas por parte de empresas interessadas em implementar megaprojetos e expropriar os territórios ancestrais para cultivo de monocultura. Portanto, para as comunidades quilombolas do Vale do Ribeira, preservar esses territórios ancestrais é cultivar a diversidade cultural e a agrobiodiversidade, além de garantir segurança alimentar e preservar os conhecimentos ancestrais. Num movimento em que humano e natureza não se dissociam, pois fazem parte de um só corpo, isso tudo faz parte da preservação da vida. Não só a vida dessas comunidades, mas a vida de todas e todos que dependem do alimento, da água, da mata ou, simplesmente, do ar para respirar. E o reconhecimento e a titulação desses espaços de direito pelo poder público são a garantia plena da liberdade daqueles e daquelas que construíram e têm construído esta nação chamada Brasil.

\section{REFERÊNCIAS}

Acselrad, H. 2010. Ambientalização das lutas sociais - o caso do movimento por justiça ambiental. Estudos Avançados 24(68):103-119. DOI: http://dx.doi.org/10.1590/S0103-40142010000100010

Alier, J. 2007. O ecologismo dos pobres: conflitos ambientais e linguagens de valoração. Tradução Maurício Waldman. São Paulo: Contexto.

Almeida, A. W. et al. (Orgs.). 2011. Cadernos de debates: nova cartografia social: territórios quilombolas e conflitos. Manaus: Projeto Nova Cartografia Social da Amazônia/UEA edições.

Almeida, S. 2018. O que é racismo estrutural? Belo Horizonte: Letramento.

Américo, M. C. 2015. Ivaporunduva e Macuanda: estudo etnográfico sobre educação, trabalho e modos de sociabilidade, Tese de Doutorado, Departamento de Educação, Faculdade de Ciências Humanas, Universidade Metodista de Piracicaba, Piracicaba. 
Andrade, A. M., L. M. F. Dias, M. F. Biesek, e R. Pasinato 2019. Sistema agrícola tradicional quilombola do Vale do Ribeira, SP, in Sistemas Agrícolas Tradicionais no Brasil. Editado por J. S. Eidt \& C. Udry, pp. 55- 92. Brasília: Embrapa.

Andrade, T., C. A. C. Pereira, e M. R. O. Andrade (Eds.). 2000. Negros do Ribeira: reconhecimento étnico e conquista do território. São Paulo: Cadernos ITESP.

Arteris S/A. 2017. Arteris Régis Bittencourt entrega segunda pista da Serra do Cafezal. Disponível em: http://www.arteris.com.br/noticias/arteris-regis-bittencourt-entrega-segunda-pista-da-serra-docafezal/. Acesso: 03 jan. 2020.

Barboza, G. S. 1992. Relatório Etnográfico Técnico-Científico sobre o Quilombo Ivaporunduva. Equipe de Articulação e Assessoria das Comunidades Negras do Vale do Ribeira (EACONE); Comissão Pastoral da Terra (CPT) e Movimento dos Ameaçados por Barragens (MOAB). Relatório etnográfico.

Berlanga, M. S. 2017. Luta pelo território é marca intrínseca do povo quilombola, in Dossiê Sistema Agrícola Tradicional Quilombola do Vale do Ribeira-SP. Organizado por A. M. C. Andrade \& A. Kishimoto, pp. 218-252. [s.l.]: Instituto Socioambiental.

Brasil. 1988. Constituição da República Federativa do Brasil. Brasília: Senado Federal.

Carril, L. F. B., 1995. Terras de Negros no Vale do Ribeira: territorialidade e resistência, Dissertação de Mestrado, Universidade de São Paulo, São Paulo.

Carvalho, M. C. P. 2006. Bairros negros do Vale do Ribeira: do "escravo" ao "quilombo", Tese de Doutorado, Instituto de Filosofia e Ciências Humanas, Universidade Estadual de Campinas, Campinas.

Coelho, A. Silva. 2014. Capitalismo como religião: uma crítica a seus fundamentos mítico-teológicos, Tese de Doutorado, Universidade Metodista de São Paulo, São Bernardo do Campo. 
Coordenação Nacional de Articulação das Comunidades Negras Rurais Quilombolas (CONAQ). (s/d). Quem somos. Disponível em: http://conaq.org.br/nossa-historia/. Acesso em: 03 jun. 2019.

Coordenação Nacional de Articulação das Comunidades Negras Rurais Quilombolas (CONAQ), e Terra de Direitos. 2018. Racismo e violência contra quilombos no Brasil. Curitiba: Terra de Direitos.

Diegues, A. 2001. O mito moderno da natureza intocada. 3. ed. São Paulo: Hucitec.

Diegues, A. 2007. O Vale do Ribeira e Litoral de São Paulo: meio ambiente, história e população. São Paulo. Disponível em: http://nupaub.fflch.usp.br/sites/nupaub.fflch.usp.br/files/color/cenpec.pdf. Acesso em: 02 dez. 2014.

Dussel, E. 2016. Transmodernidade e interculturalidade: interpretação a partir da filosofia da libertação. Sociedade e Estado 31(1):51-73. DOI: http://dx.doi.org/10.1590/S0102-69922016000100004

Dutra, M. V. F. 2011. Direitos quilombolas: um estudo do impacto da cooperação ecumênica. Rio de Janeiro: KONONIA Presença Ecumênica e Serviço.

Escobar, A. 2015. Territorios de diferencia: La ontología política de los "derechos al territorio". Cuadernos de Antropología Social 41:25-38.

Fundação Instituto de Terras do Estado de São Paulo (ITESP). 1998a. Relatório técnico-científico sobre a Comunidade de Quilombo de São Pedro, localizada nos municípios de Eldorado e Iporanga-SP. São Paulo: Secretaria da Justiça e Defesa da Cidadania.

Fundação Instituto de Terras do Estado de São Paulo (ITESP). 1998b. Relatório técnico-científico sobre a Comunidade de Quilombo de Ivaporunduva, localizada no município de Eldorado-SP. São Paulo: Secretaria da Justiça e Defesa da Cidadania. 
Fundação Oswaldo Cruz (FIOCRUZ). (2014). Mapa de conflitos envolvendo injustiça ambiental e saúde no Brasil. Núcleo Ecologias, Epistemologias e Promoção Emancipatória da Saúde. Disponível em: http:// mapadeconflitos.ensp.fiocruz.br/?conflito=pr-apos-prosperidade-exploracao-do-chumbo-e-prata-emadrianopolis-e-adjacencias-gera-passivo-ambiental-e-contaminacao. Acesso em: 03 jan. 2020.

Hayama, A. T. 2017. Unidades de conservação em territórios quilombolas: conflitos socioambientais e atuação da defensoria pública, Dissertação de Mestrado, Pontifícia Universidade Católica do Paraná, Paraná.

Herculano, S., e T. Pacheco. 2006. Racismo ambiental: I Seminário Brasileiro sobre Racismo Ambiental. Rio de Janeiro: FASE.

Instituto Nacional de Colonização e Reforma Agrária (INCRA). (s/d). Disponível em http://www.incra. gov.br/content/quilombolas. Acesso em: 25 fev. 2019.

Instituto Socioambiental (ISA). 2016. População do Vale do Ribeira está livre de Tijuco Alto. Disponível em: https://www.socioambiental.org/pt-br/noticias-socioambientais/populacao-do-vale-do-ribeiraesta-livre-de-tijuco-alto. Acesso em: 22 jan. 2019.

Instituto Socioambiental (ISA). 2018. Pequenas centrais hidrelétricas ameaçam populações tradicionais no Vale do Ribeira. Disponível em: https://www.socioambiental.org/pt-br/noticias-socioambientais/ pequenas-centrais-hidreletricas-ameacam-populacoes-tradicionais-no-vale-do-ribeira. Acesso em: 22 jan. 2019.

Instituto Socioambiental (ISA). (s/d). Tá na hora da roça. Disponível em: https://peticoes.socioambiental. org/ta-na-hora-da-roca. Acesso em: 10 jan. 2020.

Kilomba, G. 2019. Memórias da plantação: episódios de racismo cotidiano. Tradução de Jess Oliveira. Rio de Janeiro: Cobogó. 
Krug, E. 1912. Xiririca, Ivaporundyba e Yporanga. Revista do Instituto Histórico e Geográfico de São Paulo(17):259-291.

Luiz, V., L. M. Silva, M. C. Américo, L. M. F. Dias, A. Nainá, e V. Ribeiro. 2020. Roça é vida. Brasília: IPHAN.

Mignolo, W. 2007. La Idea de America Latina: la herida colonial y la opción decolonial. Trad. de Silvia Jawerbaum y Julieta Barba. Barcelona: Editorial Gedisa.

Mignolo, W. 2017. Colonialidade: o lado mais escuro da modernidade. Revista Brasileira de Ciências Sociais 32(94):e329402. DOI: http://dx.doi.org/10.17666/329402/2017

Nascimento, A. 1980. OQuilombismo - documentos de uma militância pan-africanista.Petrópolis: Editora Petrópolis.

Nascimento, M. B. 1985. O conceito de quilombo e a resistência cultural negra, in Eu sou Atlanta: sobre a trajetória de vida de Beatriz Nascimento. Editado por A. Ratts. São Paulo: Imprensa Oficial.

Oliveira, F. M. B. 2009. Mobilizando oportunidades: estado, ação coletiva e o recente movimento social quilombola, Dissertação de Mestrado, Universidade de São Paulo, São Paulo.

Pacheco, T. 2007. Desigualdade, injustiça ambiental e racismo: uma luta que transcende a cor. Combate Racismo Ambiental. Disponível em: https://racismoambiental.net.br/textos-e-artigos/desigualdadeinjustica-ambiental-e-racismo-uma-luta-que-transcende-a-cor/. Acesso em: 03 jan. 2020.

Paes, G. S. M. 2007. A Recomendação das Almas na Comunidade Remanescente de Quilombo de Pedro Cubas, Dissertação de Mestrado, Universidade de São Paulo, São Paulo.

Pasinato, R. 2017. Agricultura quilombola: formas de organização e comercialização, in Dossiê Sistema agrícola Tradicional Quilombola do Vale do Ribeira-SP. Organizado por A. M. C. Andrade \& A. Kishimoto, pp. 262-278. [s.l.]: Instituto Socioambiental. Disponível em: http://portal.iphan.gov.br/uploads/ckfinder/ arquivos/Dossi\%C3\%AA_relat_1(1).pdf. Acesso em: 03 jan. 2020. 
Pedroso Júnior, N. N., R. S. S. Murrieta, e C. Adams. 2008. A agricultura de corte e queima: um sistema em transformação. Boletim do Museu Paraense Emílio Goeldi. Ciências Humanas 3(2):153-174. DOI: http://dx.doi.org/10.1590/S1981-81222008000200003

Queiroz, R. 2006. Negros do Vale do Ribeira: um estudo de antropologia econômica. São Paulo: Edusp.

Rodovia Régis Bittencourt. (s/d). Disponível em: https://www.rodoviaregisbittencourt.com.br/tudosobre-a-rodovia-regis-bittencourt.php. Acesso em: 28 dez. 2019.

Santos, B. S. 2002. Para uma sociologia das ausências e uma sociologia das emergências. Revista Crítica de Ciências Sociais (63):237-280. DOI: https://doi.org/10.4000/rccs.1285

Santos, M. W. 2010. Saberes da terra: o lúdico em Bombas, uma comunidade quilombola (estudo de caso etnográfico), Tese de Doutorado, Departamento de Educação, Universidade de São Paulo, São Paulo.

Santos, M. 2000. Por uma outra globalização: do pensamento único à consciência universal. Rio de Janeiro: Record.

Santos, M. 2012. Da totalidade ao lugar. São Paulo: Edusp.

São Paulo (Governo do Estado). (1957). Lei n. 3.962, de 24 de julho de 1957. Dispõe sôbre o processamento das legitimações de posse em terras devolutas. Disponível em: https://www.al.sp.gov.br/repositorio/ legislacao/lei/1957/lei-3962-24.07.1957.html. Acesso: 03 jan. 2020.

Serviço Geológico do Brasil (CPRM). (s/d). Missão, visão, valores e princípios. Disponível em: http:// www.cprm.gov.br/. Acesso em: 12 jan. 2020.

Silva, L. A. L., e Moraes, O. R. 2019. Racismo ambiental, colonialismos e necropolítica: direitos territoriais quilombolas subjugados no Brasil, in Ensaios sobre racismos. Organizado por E. F. Lima et al., pp 33-49. São Paulo: Balão Editorial 
Silva, M. R. 2017. Potencial fitorremediador de Canavalia ensiformees em Neossolos Fluvicos do Vale do Ribeira contaminadores com chumbo, arsênio e zinco, Dissertação de Mestrado, Universidade Estadual de Campinas, São Paulo.

Silveira, P. C. B. 2003. Relatório Técnico Científico sobre os remanescentes da comunidade de quilombo de Bombas, Iporanga/SP. São Paulo: ITESP.

Stucchi, D. et al. 1998. Laudo Antropológico: Comunidades Negras de Ivaporunduva, São Pedro, Pedro Cubas, Sapatu, Nhunguara, André Lopes, Maria Rosa e Pilões - Vale do Rio Ribeira de Iguape -SP. São Paulo: Ministério Público Federal em São Paulo.

Supremo Tribunal Federal (STF). (s/d). STF garante posse de terras às comunidades quilombolas. Disponível em: http://www.stf.jus.br/portal/cms/verNoticiaDetalhe.asp?idConteudo=369187. Acesso em: 15 jan. 2019.

Tomazela, J M. 2008. Justiça manda titular quilombo Ivaporunduva, em SP. Estadão. Disponível em: https://politica.estadao.com.br/noticias/geral,justica-manda-titular-quilombo-ivaporunduva-emsp,296106. Acesso em: 03 jan. 2020. 